\title{
Transnational childhoods: British Bangladeshis, identities and social change
}

\section{Francesco Della Puppa}

To cite this article: Francesco Della Puppa (2016): Transnational childhoods: British Bangladeshis, identities and social change, Ethnic and Racial Studies

To link to this article: http://dx.doi.org/10.1080/01419870.2016.1266011

$$
\text { 曲 Published online: } 08 \text { Dec } 2016 .
$$

Submit your article to this journal $\sqsubset$

III Article views: 20

Q View related articles $\widetilde{ }$

View Crossmark data $₫$ 


\section{BOOK REVIEW}

\section{Transnational childhoods: British Bangladeshis, identities and social}

change, by Benjamin Zeitlyn, London, Palgrave MacMillan, 2015, viii+189

pp., $£ 95.00$ (hardcover), ISBN 978-1-137-42644-4

I was aware of the author Benjamin Zeitlyn through his first publication, which analysed the migration from Bangladesh to the Mediterranean Europe, an original work that illuminated a poorly investigated issue among the panorama of the studies on the so-called Bangladeshi diaspora.

With his recent monograph, "Transnational Childhood: British Bangladeshis, Identities and Social Change," likely the outcome of $\mathrm{PhD}$ research, the author confirms the originality of the choice for the subject of study and the perspective of his observations, in addition to the theoretical and methodological rigour that has always characterized his scientific work.

The text focuses on a subject that has only been marginally considered by those involved in the study of the migration from South-East Asia and the Bangladeshi diaspora. The author considers processes of constructing a diasporic identity of the British Bangladeshi children and the social experiences of transnational families within the framework of the transformations of social horizons and demographic identity of the Europe marked by the economic crisis and the UK crossed by the Brexit.

Zeitlyn provides the results of a multi-sited ethnography carried out between the London borough of Islington and the rural district of Sylhet in Bangladesh, during which he observed and experienced the lives of British Bangladeshi children in the physical and social spaces of Poynder Primary School, in their homes with their parents on the border of Islington and Hackney, as well as in the households of their extended families in the country of origin of their parents.

The study employs an exhaustive quantitative framework and a constant confrontation with scientific debate and theoretical elaboration. This discussion is not limited to a single chapter, but accompanies and stimulates the reader throughout the text, adopting an approach and a writing style that is distinctly reflexive and an acute methodological elaboration on the process of ethnography, on the postures and negotiations, placements and shifts experienced by the researcher as part of the delicate fieldwork involving relationships with children, as well as on the mistakes and misunderstandings that ethnographic work can induce, but that at the same time can deliver useful tools for gaining knowledge.

From a theoretical point of view, the text has its foundations in the constructs of Pierre Bourdieu, which constitute its categories of interpretation and analysis. The author identifies three social fields - that are also fields of struggle - within which the subjects of his research are moving: the "British-Bangladeshi social field" (11), described as a transnational social field deployed between the two poles of migration; the one constitutes by the school attended by the British Bangladeshi children, to whom is assigned the role of social order reproduce; 
the one called "Islamic social field" (ibid.), represented by the Qur'an reading classes frequented by British Bangladeshi children, by a sense of belonging to the international community of the umma, as well as by the different interpretations of Islam and its intersections with other memberships.

Within these social fields, different actors (first of all, British Bangladeshi children, but also their parents, different generations of Bangladeshis in the UK, members of their extended families in Bangladesh, the British education system, the State, the religious leaders and the different interpretations of Islam, etc.) accumulate, flaunt and bring into play different capitals. Alongside the forms of capital of the Bourdieusian analysis - economic and material capital, cultural capital, social capital and symbolic capital - the author identifies others, such as security capital, the accumulation of which may partly explain the migration from Bangladesh to the UK, as well as sacred capital, a type of capital British Bangladeshi children will have in greater amounts than their own parents as a result of Qur'an lessons.

Far from being passive and powerless objects, British Bangladeshi children albeit in a context riddled with contradictions and ambivalences - arise as subjects who can strategically use their constant movements and their different positions within and between the different transnational social fields in which they move to their advantage, thus practicing an expert and strategic conversion of the different forms of capital they have accumulated.

Zeytlin presents the contours of social actors who practice forms of multi-sited and multidimensional citizenship, although this concept is not explained by the author. On the contrary, in the first pages of the text, the theoretical construct of intersectionality is introduced and the author explicitly refers to the interweaving of the many "axes of identity" (25), but this interpretive lens has only rarely been adopted.

In particular, Zeytlin illustrates that, through these social fields deployed on global and transnational level, the habitus of British Bangladeshi children is produced and reproduced, and the gap between their social postures and their social order interpretation and those internalized by their parents is constructed, in line with the different generational styles and different opportunities of accumulation of different forms of capital that characterize their trajectories.

However, it should be noted that there is the risk of a too mechanistic and too "intentional" interpretation and use of the concept of habitus: sometimes it is presented as an aspect that generations of parents will consciously attempt to shape and hand down to their children, rather than the incorporation and result of the process of embeddedness - the more unconscious this process is, the more effective it will be (and vice versa) - of a structured and structuring structure that emerges from the social positioning of the agents involved.

Observing children of British families of Bangladeshi origin in London and making innovative global use of the Bourdieusian constructs, Zeitlyn observes the social and family changes due to migration and diasporic processes, as well as the dynamics of identity and social reproduction within a transnational and diasporic context. 
In its final pages, the text cannot avoid a reflection on power, doxa and the strategies of resistance that, inevitably, any form of symbolic violence contains within itself. It is here that, alongside Bourdieusian perspectives, the author compares his theoretical analysis with Foucault. This trialogue, however, even if relevant and well-conducted, arrives suddenly and the reference to this author appears poorly contextualized and rather disconnected from the path that Zeitlyn has taken from the start.

Nonetheless, "Transnational Childhood: British Bangladeshis, Identities and Social Change" is an essential contribution to the understanding of the experiences of the children of families divided by continents, transnational dynamics and the Bangladeshi diaspora, as well as an excellent application of Bourdieusian constructs in ethnographic research.

Francesco Della Puppa Department of Philosophy, Sociology, Education, Applied Psychology, University of Padova

Q francesco.dellapuppa@unipd.it

(C) 2016 Francesco Della Puppa http://dx.doi.org/10.1080/01419870.2016.1266011 